NBER WORKING PAPER SERIES

\author{
KEYNESIANISM, PENNSYLVANIA \\ AVENUE STYLE: SOME ECONOMIC \\ CONSEQUENCES OF THE EMPLOYMENT \\ ACT OF 1946
}

J. Bradford De Long

Working Paper 5611

\author{
NATIONAL BUREAU OF ECONOMIC RESEARCH \\ 1050 Massachusetts Avenue \\ Cambridge, MA 02138 \\ June 1996
}

I owe thanks to the National Science Foundation and to the Alfred P. Sloan Foundation for financial support. Conversations with Alan Auerbach, John Auten, John Berry, Alan Blinder, Alan Cohen, Barry Eichengreen, Robert Gillingham, Peter Hall, Alan Krueger, Michael Levy, Charles Maier, Alicia Munnell, Christina Romer, David Romer, Larry Summers, Tim Taylor, and James Wilcox have been extremely helpful. This paper is part of NBER's research programs in Monetary Economics, and the Development of the American Economy. Any opinions expressed are those of the author and not those of any government or institution, or the National Bureau of Economic Research.

(C) 1996 by J. Bradford De Long. All rights reserved. Short sections of text, not to exceed two paragraphs, may be quoted without explicit permission provided that full credit, including (C) notice, is given to the source. 


\title{
KEYNESIANISM, PENNSYLVANIA AVENUE STYLE: SOME ECONOMIC CONSEQUENCES OF THE EMPLOYMENT ACT OF 1946
}

\begin{abstract}
The Employment Act of 1946 created the Council of Economic Advisers as an institution, and serves as a convenient marker of a broader change in opinions and sentiments: the assumption by the federal government of the role of stabilizing the macroeconomy.

The magnitude of this shift should not be understated: before the Great Depression strong currents of macroeconomic theory held that stabilization policy was positively unwise. It solved problems in the present only by storing up deeper and more dangerous problems for the future. Yet as a result of the shift in opinions and sentiments marked by the 1946 Employment Act, no government since WWII has dared do anything other than let fiscal automatic stabilizers swing into action during recession. This may well have been a significant force tending to moderate the post-WWII business cycle.

But the bulk of the CEA's time and energy now and in the past has been devoted not to macroeconomic but to microeconomic issues. The CEA has been one of the few advocates of the public interest in allocative efficiency present in the government. The CEA has been more successful in its microeconomic role than many would have predicted ex ante. Its relative success can be traced to the staffing pattern set up by two strong early chairs-Arthur Burns and Walter Heller-who made sure that the CEA staff was largely composed of short-term appointees whose principal loyalties were to the discipline of economics, and who as a result were less vulnerable to the processes that block pressure for allocative efficiency in other parts of the government.
\end{abstract}

\author{
J. Bradford De Long \\ Department of Economics \\ Evans Hall \\ University of California, Berkeley \\ Berkeley, CA 94720-3880 \\ and NBER
}




\title{
Keynesianism, Pennsylvania Avenue Style: Some Economic Consequences of the Employment Act of 1946
}

\author{
J. Bradford De Long'
}

\section{November 1995; Revised March 1996}

J. Bradford De Long is Associate Professor of Economics, University of California, Berkeley, California, and Research Associate, National Bureau of Economic Research, Cambridge, Massachusetts.

The 1946 Employment Act declared that it was the "continuing policy and responsibility" of the federal government to "coordinate and utilize all its plans, functions, and resources... to foster and promote free competitive enterprise and the general welfare; conditions under which there will be afforded useful employment for those able, willing, and seeking to work; and to promote maximum employment, production, and purchasing power" (see Heller (1966), Bailey (1950)). The Act also established the President's Council of Economic Advisers and the Congress's Joint Economic Committee $^{2}$, and called on the President to estimate and forecast the current and future level of

${ }^{11}$ I owe thanks to the National Science Foundation and to the Alfred P. Sloan Foundation for financial support. Conversations with Alan Auerbach, John Auten, John Berry, Alan Blinder, Alan Cohen, Barry Eichengreen, Robert Gillingham, Peter Hall, Alan Krueger, Michael Levy, Charles Maier, Alicia Munnell, Christina Romer, David Romer, Larry Summers, Tim Taylor, and James Wilcox have been extremely helpful. The views expressed are my own, and are not the views of any government or institution.

${ }^{2}$ I have little to say abou tthe Congressional Joint Economic Committee. At times it has served as an interesting forum for debate on issues of economic policy. The split between the majority and the 
economic activity in the United States. It thus committed the federal government to the business of macroeconomic management.

\section{Or did it?}

Consider a more recent piece of legislation with a similar tone and more expansive declared goals that has had next to no effect on American macroeconomic policy. In 1978, the HumphreyHawkins Act committed the federal government to reducing the unemployment rate to four percent by 1983 and to maintaining it thereafter. It committed the federal government to reducing the inflation rate to zero by 1988. It also called for the reduction of federal government spending to "the lowest level consistent with national needs," and for spending more money on farm price supports (Weir (1992)). Finally, it required the Chairman of the Federal Reserve to testify before the Congress twice a year on the state of the macroeconomy.

In spite of its broad goals, sweeping language, and bold commitments, the HumphreyHawkins Act has had no effect on anything, save that the Federal Reserve Chairman does give his periodic "Humphrey-Hawkins testimony"; as a result the workload of the Federal Reserve staff is slightly higher (and perhaps the "transparency" and accountability of Federal Reserve actions has improved.)

One possible conclusion from Humphrey-Hawkins is that laws which mainly establish goals and do not build institutions have no independent effects. However, laws that establish goals can and do serve as markers of changes in opinions, perceptions, and aims. When people then speak of the effects of such a law, in many cases they are using "the law" as a shorthand marker to describe changes in the hearts and the minds of the people. Whether the goal is achieved or pursuit of the goal effects and constrains public policy depends on the depth of the change in hearts and minds.

minority staff has often been very wide, and the standard pressures from other committees seeking to maintain their jurisdiction unimpeded have had the expected effects. 
The 1978 Humphrey-Hawkins Act in large part went against the flow of shifting opinions and sentiments. It was passed for short-term political advantage, and was correctly expected to be a dead letter. The law created no institutions, and marked no changes in hearts and minds toward its goals, and so it had no effect.

The Employment Act of 1946 is a much more complicated case. It certainly marked the commitment of the federal government to the macroeconomic management business. As originally introduced, the Full Employment Act required the president to submit a "National Production and Employment Budget," or NPEB, that would set out a spending and legislative program for the current legislative session that would "assure a full employment volume of production" in the following fiscal year-a fiscal year that would begin approximately six months after the submission of the NPEB. This institutional setup would have solidly entrenched a strong bias toward active countercyclical fiscal policy in the core of the American Executive Branch.

As finally enacted, the Employment Act called for an annual Economic Report "setting forth... current and foreseeable trends in the levels of employment, production, and purchasing power... and a program for carrying out the policy" to promote "conditions under which there will be afforded useful employment for those able, willing, and seeking to work." The enacted bill is a weaker signal of the government's commitment to macroeconomic management than was the initial proposal, but it is a signal.

The Employment Act of 1946 also created an institution: the Council of Economic Advisers, or CEA. But its creation of the CEA as we know it today - one chair, two members, and a senior staff of 15 , almost invariably drawn from and planning to return to the professoriate - is best described as an accident. The original proposal was for an expansion of the Budget Bureau, or perhaps for an "Office of Director of the National Budget." Other institutional arrangements were proposed-a Federal Trade Commission or Federal Reserve Board-like structure for the Council of Economic Advisers, with members confirmed by the Senate for five-year overlapping terms; the Treasury Secretary's proposal of a cabinet-level economic policy coordination committee chaired by (who else?) the Treasury 
Secretary; and other institutional arrangements. The staffs of such alternative institutions would have likely not been economists on one- or two-year rotations from the professoriate, but the mix of civil servants and ex-campaign workers that make up the operating levels of the White House staff. ${ }^{3}$

My reading of the legislative history is that the Truman Administration dropped the ball. It should have been much more concerned about institutional arrangements. I believe that Congress thought (incorrectly, it turned out) that use of the Senate's advise-and-consent power over CEA nominees (and appropriations) could influence macroeconomic policy planning in the Executive Office of the President.

Only because of the institution-building of Arthur Burns and Walter Heller did the CEA acquire the recruitment and staffing patterns that it has today.

Thus there are two strands to follow in analyzing the 1946 Employment Act. First come the institutions: how they functioned and whether they mattered. Second comes the shift in sentiments and aims that led to the passage of the Employment Act, and of which the Act serves as a convenient marker. The two strands are interwoven in part because the CEA has served as the channel through which shifts in the climate of opinion have their effect on the Executive Branch of the U.S. government, and in part because the authority of the Council has been in large part derived from the same intellectual currents that underpinned the enactment of the Act.

\section{Stabilization Policy}

The largest shift in policy marked by the 1946 Employment Act is the post-WWII practice of allowing the government's automatic stabilizers to function. Not since the Great Depression have

\footnotetext{
${ }^{33}$ Such a cabinet-level economic policy coordinating committee has often existed (and, when it has existed, has often been chaired by the Secretary of the Treasury). The head of such a committee (when not the Secretary of the Treasury) and the staff of such a committee have, however, typically been very different from the members and staff of the CEA.
} 
mainstream legislators or opinion leaders called for fiscal austerity in the midst of recession. As a result, the federal government's budget exhibits substantial cyclical variation, sliding into deeper deficit in recessions, and moving toward balance or into surplus as the economy expands.

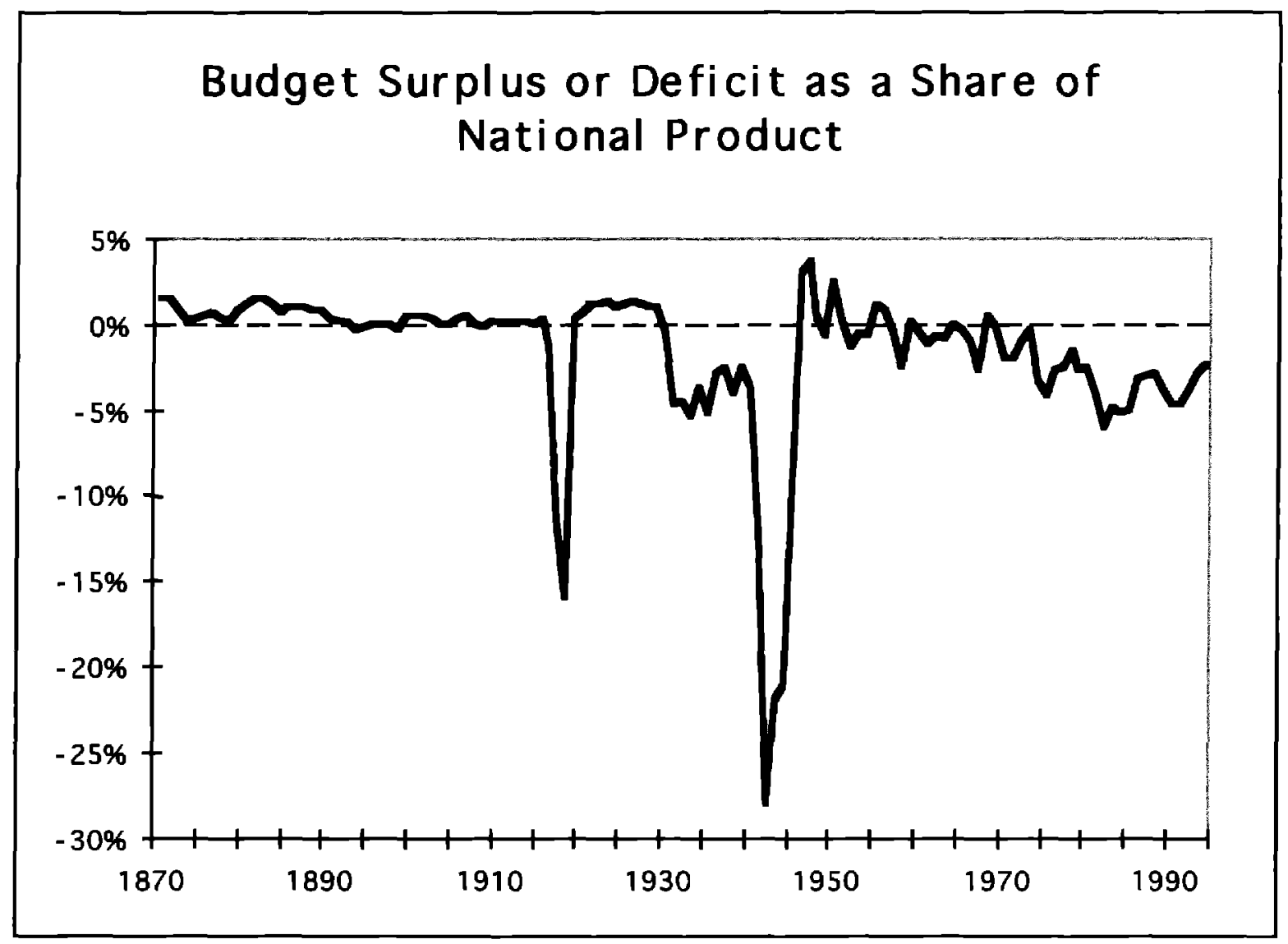

There have been powerful (and I believe correct) arguments that the federal govemment has neither the knowledge of economic structure nor the institutional capacity to do any more than allow fiscal automatic stabilizers to function (see Friedman (1953); Eisner (1969); Stein $(1969,1980$, 1984)). But in political terms, a simpler argument has held sway: that the federal deficit in time of recession is "cyclical," and that steps to reduce it immediately would aggravate the recession, have been effective trump cards in public policy debates. Since World War II, at least, this argument has kept policy makers from seeking budget balance when unemployment is high. 


\section{Pre-Keynesian Fiscal Theory}

The gap between this calm acceptance of automatic stabilizers and the cyclical fiscal deficits they produce and pre-WWII attitudes is extremely large. Recall that Franklin Roosevelt made Herbert Hoover's failure to balance the federal budget in 1932 an issue in the 1932 presidential election. Or consider Joseph Schumpeter (in Brown, 1934), writing from Harvard in the middle of the Great Depression that there was a:

presumption against remedial measures... [because] policies of this class are particularly apt to...produce additional trouble for the future.... [For depressions are] not simply evils, which we might attempt to suppress, but...forms of something which has to be done, namely, adjustment to...change... [and] most of what would be effective in remedying a depression would be equally effective in preventing this adjustment.

In what Haberler (1937) classified as "monetary over-investment" theories of the business cycle, depressions were born either from excessively easy monetary policy or out of ex post overoptimistic expectations. When monetary policy ceased to be too easy, or when investors and businesses recognized that their forecasts of future growth had been overoptimistic, the economy was left with a large inventory of investment projects that were unprofitable. True and sustainable economic recovery was not possible until the economy's overinvestment overhang had been "liquidated"-and the painful depression was this process of liquidation. Monetary and fiscal policies to moderate the depression would, in this conceptual framework, keep workers and firms producing in unsustainable lines of business and levels of capital intensity. Such attempts to alleviate the depression would make the depression less deep only at the price of making it longer, and would add to the total sum of human misery (Hayek (1935)). 
Indeed, Lionel Robbins (1934) went as far as to blame the tiny steps toward moderating the decline in the money stock and boosting fiscal demand that governments undertook over 1929-1933 for the persistence of the Great Depression into the mid-1930s.

This doctrine - that in the long run the Great Depression would turn out to have been "good medicine" for the economy, and that proponents of stimulative monetary and fiscal policies in the 1930s were shortsighted enemies of the public welfare - did draw some anguished cries of dissent (Salant (1989)). For example, Keynes (1931) tried to ridicule it:

Some austere and puritanical souls regard [the Great Depression] both as an inevitable and a desirable nemesis on so much [late 1920s] overexpansion, as they call it; a nemesis on man's speculative spirit. It would, they feel, be a victory for the mammon of unrighteousness if so much prosperity was not subsequently balanced by universal bankruptcy. We need, they say, what they politely call a 'prolonged liquidation' to put us right. The liquidation, they tell us, is not yet complete. But in time it will be. And when sufficient time has elapsed for the completion of the liquidation, all will be well with us again....

I do not take this view. I find the explanation of the current business losses, of the reduction in output, and of the unemployment which necessarily ensues not in the high level of investment which was proceeding up to the spring of 1929, but in the subsequent cessation of this investment. I see no hope of a recovery except in a revival of the high level of investment. And I do not understand how universal bankruptcy can do any good or bring us nearer to prosperity...

Ralph Hawtrey (1938), an advisor to the British Treasury and the Bank of England, called it the equivalent of “crying, 'Fire! Fire!' in Noah's flood” (Temin (1989)). The doctrine was not universally taught; it was, as Milton Friedman would later recall absent from Chicago. But perhaps the presence of such doctrines at other universities - which Salant (1989) terms the "crime and punishment" theory of business cycles-helped induce bright economists to rebel and become Keynesians. 


\section{Automatic Stabilizers}

Automatic stabilizers may not have significantly reduced post-WWII business-cycle variability below pre-Depression levels (Romer (1986). And any belief that automatic stabilizers have a significant effect on business cycle variability does depend on liquidity constraints being pervasive in the economy (De Long and Summers (1986)). Nevertheless, the shift in the cyclical behavior of the federal budget, considered as a sea-anchor for the economy's level of total spending, is impressive.



A good deal of this increase in the magnitude of automatic stabilizers comes from the increase in the size of the government as a share of national product. The post-WWII federal government taxes and spends one-sixth or more of national product in peacetime. The Depression-era government taxed 
5 to 7 percent and spent 8 to 10 percent of national product. The pre-Depression government taxed and spent at most 5 percent, and more typically 2 of national product in peacetime.

With a large federal government, automatic stabilizers are significant. If revenues are one-fifth of national product, a 5-percent fall in output relative to previous forecasts would "automatically" produce a deficit of 1 percent of national product from the revenue side alone, even in the absence of overall progressivity. When, as before the Great Depression, both spending and revenues are 5 percent of national product or less, "automatic stabilizers" cannot have any macroeconomic significance.

Table 1 summarizes how the federal fiscal balance responded to cyclical shifts in production and employment using simple regressions of the federal fiscal balance (as a share of national product) on the unemployment rate (using annual data, for fiscal years, and applying Romer's (1986) suggested correction to pre-Depression estimates of unemployment rates). These regressions combine the effects of automatic stabilizers that were allowed to operate (and not offset by attempts to move toward budget balance in recession) and discretionary countercyclical fiscal policy.

\section{Table 1}

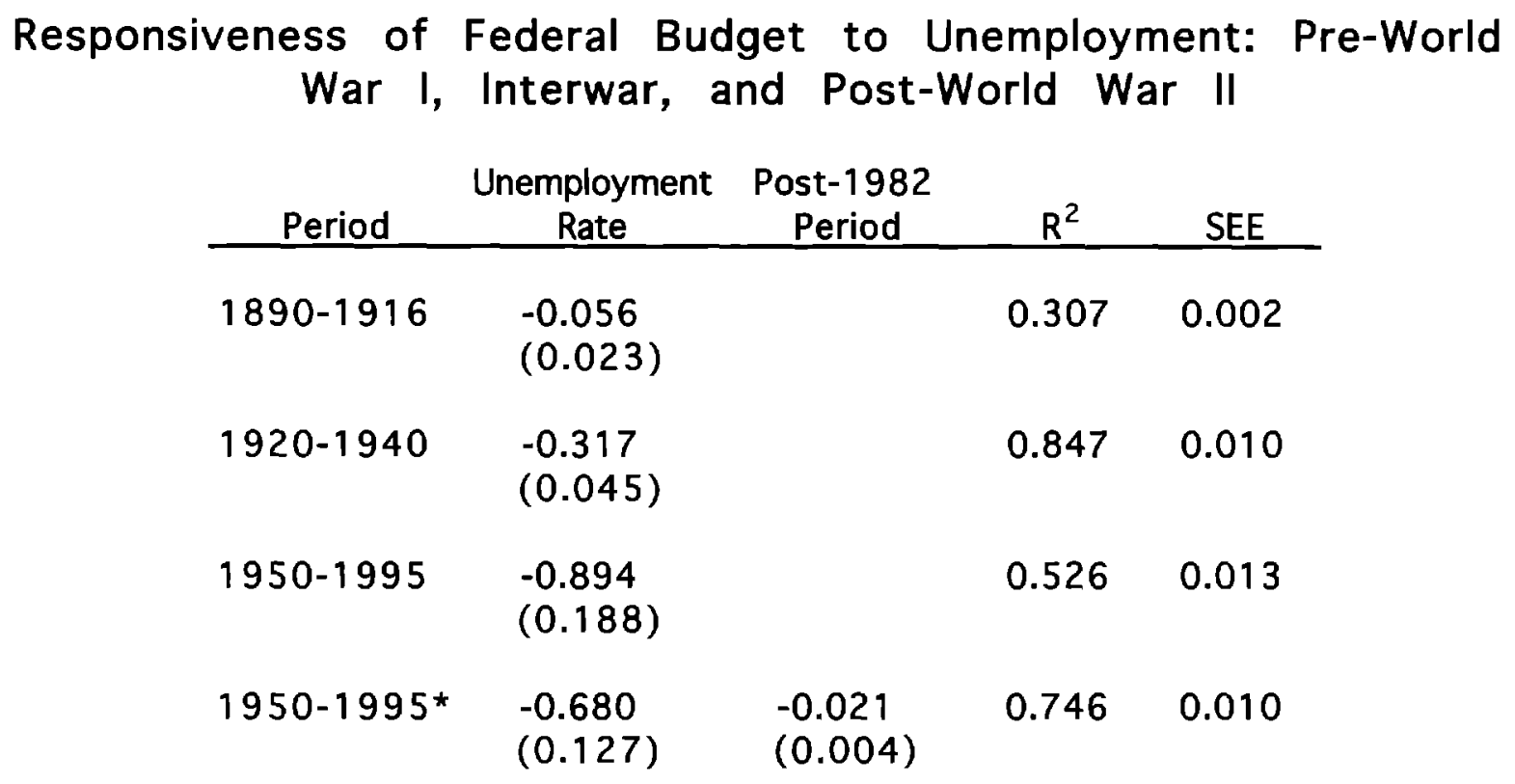


To no one's surprise the pre-WWI era shows no signs of stabilizing fiscal policy: the federal budget balance is correlated with unemployment, but the small size of the federal government means that a 5 percentage-point rise in the unemployment rate would be associated with only an 0.28 percentage-point rise in the federal deficit as a share of national product.



The interwar period shows a degree of stabilization: a 5 percentage-point increase in the unemployment rate is associated with a 1.6 percentage-point increase in the deficit as a share of national product. The bulk of this effect comes from discretionary federal relief expenditures during the Great Depression, rather than from the tax side: between 1929 and 1933 revenues remained roughly 
constant as a share of national product as nominal national product fell by more than 45 percent. By contrast, nominal federal expenditures rose by 50 percent.

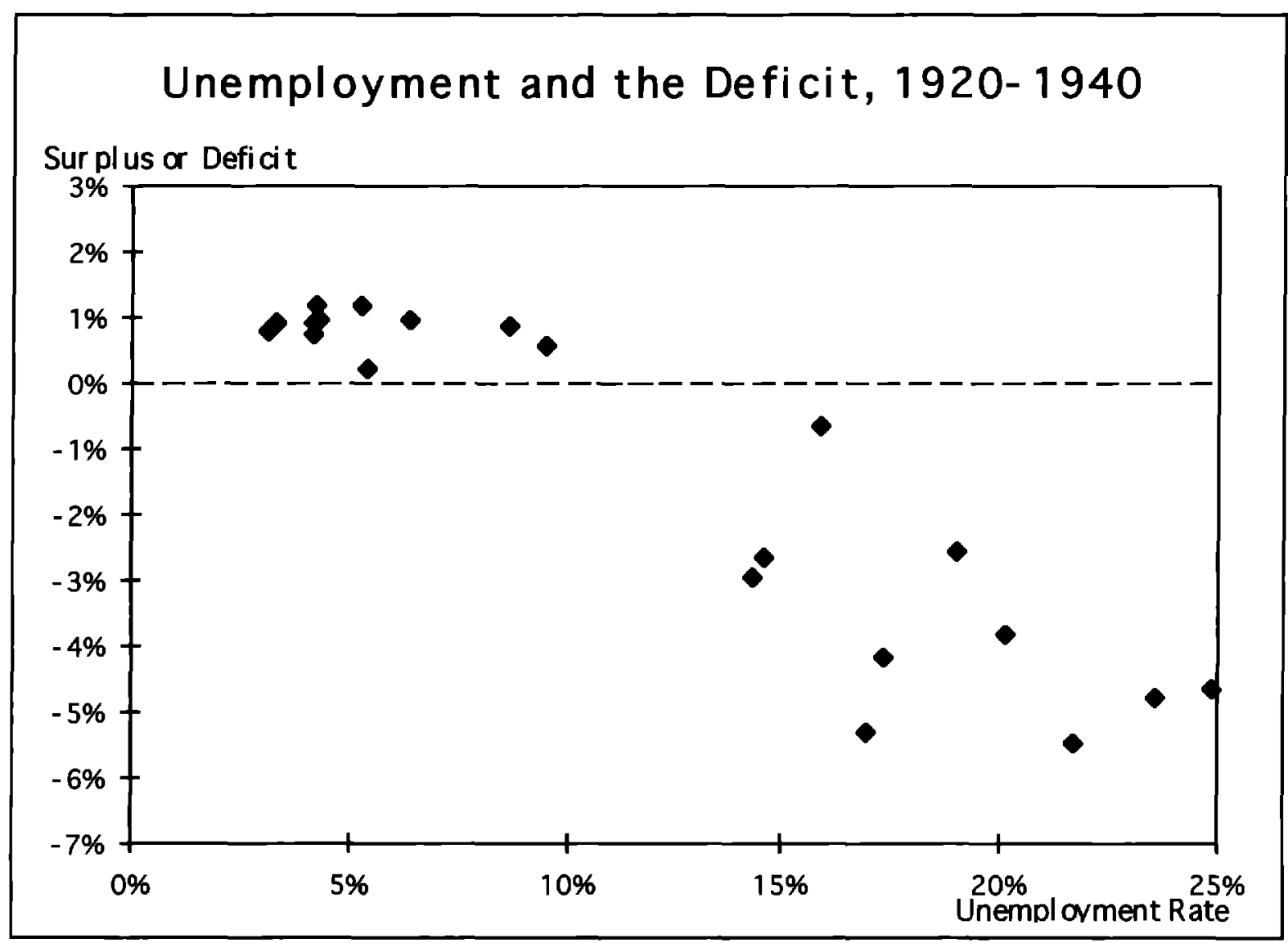

The post-World War II period shows the greatest cyclical responsiveness of fiscal balance to unemployment. A 5 percentage-point increase in the unemployment rate is associated with a 4.5 percentage-point increase in the federal deficit as a share of national product over the post-World War II period as a whole. Allowing for a one-time jump in the structural deficit in the early 1980 s as a result of the change in America's budget politics from the Reagan 1981 tax cut leads to a slightly smaller estimate of overall fiscal cyclical stabilization: a five percentage-point increase in the unemployment rate is associated not with a 4.5 but with a 3.5 percentage-point increase in the federal deficit as a share of national product. 




\section{Post-World War II Discretionary Fiscal Policy}

The bulk of this increase across time in the countercyclicality of the federal budget is the result of the budget's growing size. The commitment to macroeconomic management has checked pressures for fiscal "prudence" that would otherwise have led to procyclical discretionary fiscal policy. In the post-WWII era, at least, discretionary fiscal policy has given little aid to stabilization, and the degree of countercyclical movement in the federal budget balance has been very close to that which would have been generated by the automatic stabilizers alone.

Looking back at the budget since World War II, it is difficult to argue that on balance “discretionary" fiscal policy has played any stabilizing role (see Gordon (1980); De Long and 
Summers (1986)). Walter Heller could find one case of successful discretionary stabilization stabilization policy - the Kennedy-Johnson tax cut-to cite in his New Dimensions of Political Economy (Heller (1966)). But other concrete cases are lacking (see, for example, Eisner (1969)).

The basic difficulty is that recessions are not expected, are not forecasted, and develop rapidly. Economic policy makers work with shaky data from one quarter or so in the past. Enacting legislation takes two or three quarters if not two to three years. Appropriated funds require two additional quarters before they are spent on any substantial scale. And by that time the "need" for stimulus has passed.

The U.S. government lacks the knowledge to design and the institutional capacity to execute a countercyclical discretionary fiscal policy in response to any macroeconomic cycle of shorter duration than the Great Depression itself.

By contrast, automatic stabilizers swing into action within the current quarter. A fall in incomes leads to a shortfall in revenues - and an increase in the deficit-as soon as witholdings reach the Federal Reserve. It is difficult to imagine how alternative policy instruments could deliver such a within-the-quarter response to shifts in spending and employment.

Whether the growth of automatic stabilizers has been accompanied by a reduction in postWWII business cycle variability below pre-Depression levels is a matter of debate, in view of Romer's (1986) convincing demonstration that any such reduction has not been very large. Those who, like me, believe that automatic stabilizers have had beneficial effects point to large shocks-like the oil-price supply-shock of 1973 -found in the post-WWII but absent from the pre-Depression period. We argue that point estimates of cylicial variability show some stabilization. We claim that the issue is not stabilization relative to pre-Depression but relative to pre-WWII experience, and that the Great Depression is a draw from the universe of potential pre-Keynesian business cycles.

I believe these arguments. I make each of them at least once a month. Nevertheless, attempting to reconcile the quantitative estimates of Romer (1986) with a belief in the effectiveness of automatic stabilizers does not leave me feeling entirely... comfortable. 


\section{"Structural" Deficits}

There is an important argument that the belief in fiscal policy as a tool of economic stabilization has had harmful consequences for the economy as a whole. Buchanan and Wagner (1977) argue that deficits are dangerous because voters are myopic: when spending is raised and taxes are raised to finance the extra government spending, voters feel both the pain of reduced after-tax incomes and the benefits of spending programs and can judge whether the one is worth the other; when spending is raised and financed by borrowing, voters feel the benefits from spending but do not sense the true resource cost imposed by the higher future taxes (or the hyperinflation) required by indebtedness. The consequence? A government that is "too large," in that in engages in spending programs that do not provide social benefits equal to their resource costs, and a heavier tax burden on future generations.

Democratic politics applied to government spending, Buchanan and Wagner (1977) argue, function well only as long as deficits are effectively prohibited-regarded as a dire moral evil. Thus arguments that deficit spending could be useful as a tool of stabilization policy might undermine the polity's immune system that prevents the emergence of borrow-and-spend as standard political operating procedure. The adoption of borrow-and-spend threatens economic growth: here in the United States we are still waiting for even the first sign of any endogenous rise in private savings to offset the "structural" federal budget deficits of the past fifteen years.

It is hard to look back at the politics of America's federal deficit since 1980 and not conclude that there is a good deal of truth in Buchanan and Wagner's argument. The basic economic message is simple enough: "Cyclical deficit-good. Structural deficit—bad." Yet this message appears to be a message that is just a little bit too hard for official Washington to hold on to.

There are alternative explanations for the emergence of structural deficits in the 1980s. For example, Auerbach (1994) stresses the necessity of slowing the preplanned growth of federal spending 
in the aftermath the post-1973 productivity growth slowdown and its consequent effect on the growth of the revenue base. Yet it is hard to argue that these alternative explanations are the whole story.

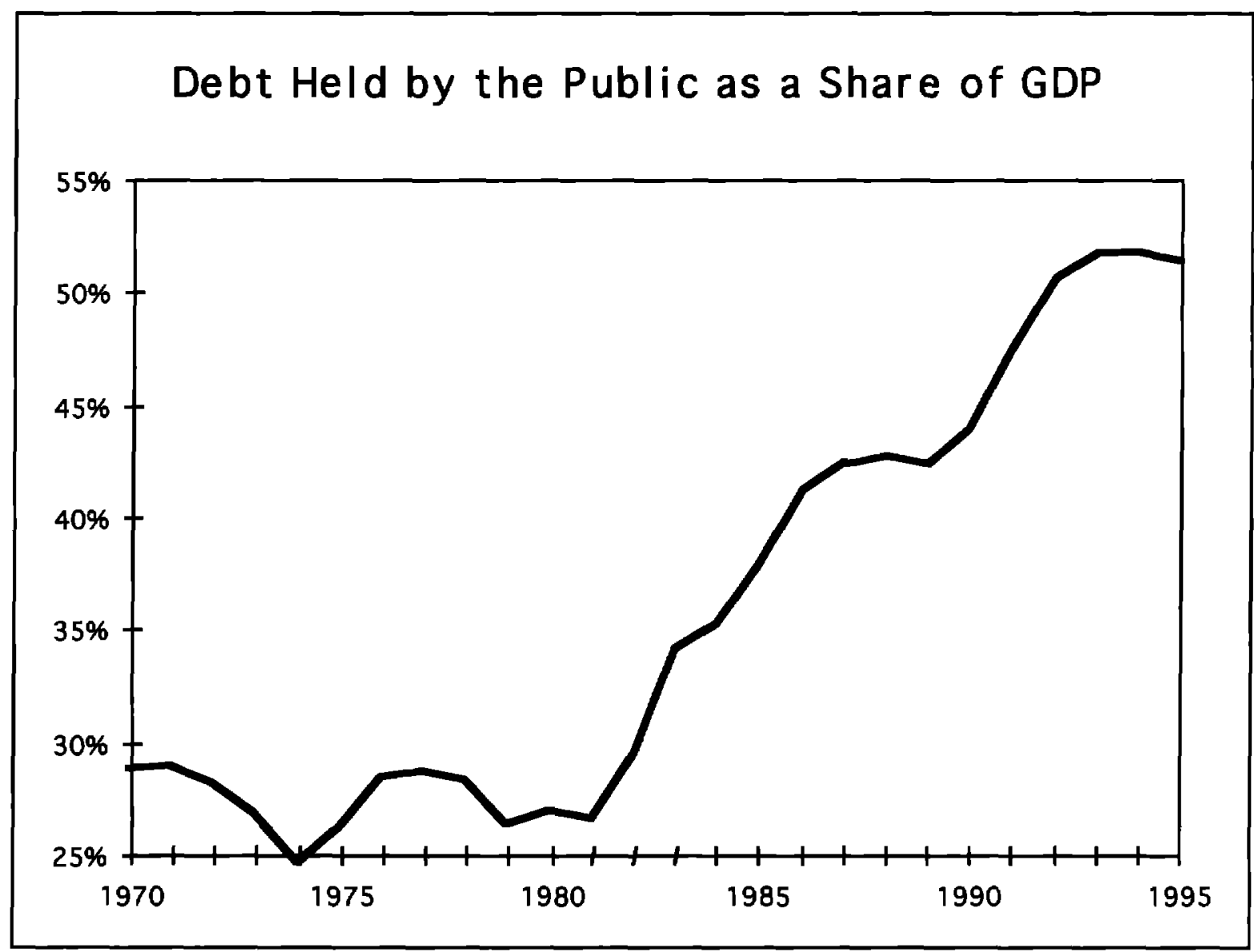

It is a heavy irony that made the American political party usually seen as most sympathetic to Buchanan's general philosophy - the Republicans - the carrier of the policies that he feared would emerge from the use of fiscal policy for macroeconomic stabilization. 


\section{Monetary Policy}

Whether the fall in nominal monetary aggregates during the slide into the Great Depression best seen as a mistake of monetary policy or as a shortfall in demand for money is an old argument. In the first case, the underlyin gproblem was the failure of the Federal Reserve to shovel enough reserves into the system fast enough; in the second, it was the temporary collapse of the economy's financial intermediation "technology" under debt and deflation (Bernanke (1994)). Would a marginally morerapid expansion of the high-powered money stock have reduced the size of the Great Depression, or simply led to a marginally larger decline in the deposit-reserves ratio? I am not confident that I know the answer.

I do, however, know that the same shifts in opinion and sentiment that made Congress announce in 1946 that macroeconomic stabilization was "the continuing responsibility and policy" of the federal government have also led the post-WW II Federal Reserve to make monetary policy with an eye not just on price stability but on a whole host of other factors as well. It is impossible to believe that we will see a repeat of the 1929-1933 experience, during which the Federal Reserve largely ignored the fall in monetary aggregates because it saw money and credit as "easy" in the sense that credit-worthy borrowers (of whom there were very few by 1933) could still borrow at very low nominal (but high real) rates of interest.

The adoption by the Federal Reserve of the mission of trying to keep unemployment from rising "too much" above its natural rate has had costs: monetary policy carried out in the pre-WWII manner would not have allowed the inflation of the 1970s. But even in the aftermath of the Volcker disinflation, the Federal Reserve continues to act as though bringing unemployment down whenever it rises far above its natural rate is a high priority: in the most recent business cycle, the Federal Reserve pushed real short-term interest rates to and held them at negative levels from late 1991 until the beginning of 1994. Here, too, the shift in the concerns and missions of economic policy makers signalled by the 1946 Employment Act continues to hold. 


\section{Microeconomic Efficiency}

In recent years, at least, macroeconomic policy management has not been the most timeconsuming mission of the CEA. In the absence of belief in and plans for discretionary fiscal policy, the macroeconomic stabilization policy roles of the CEA are smaller. One role remaining is the protection of the fiscal automatic stabilizers from policy changes that might disrupt their operation; for example, across different administrations the CEA has been an effective lobbyist against versions of balancedbudget proposals that would enforce year-by-year balance no matter what the level of the unemployment rate

The CEA does communicate its own view of the economy to the Federal Reserve, with the hope of reducing the possibility that the Federal Reserve will talk itself into a false vision of the economy. It attempts to communicate the Federal Reserve's view of the universe to the rest of the Administration. It attempts to persuade various Assistants to the President that Federal Reservebashing has significant costs and few benefits. It helps the President convince the press that he understands how the economy is working, and that the current Administration's economic policies are appropriate. And it writes the annual Economic Report of the President.

But these tasks all together consume perhaps 70 senior staff and member person-months a year. The Council of Economic Advisers has some 180 senior staff and member person-months available.

The rest of the Council of Economic Advisers' time is spent on "microeconomic" issues, attempting to inject a sense of the public interest (sir, consumers aren't organized and demanding meetings with you every week, but they would be significantly harmed by this policy); of the fact that the economy is an equilibrium system in which accounting identities hold (sir, if private savings remain anemic and the administration is lucky enough to see an investment-led recovery, we will see a sharply-rising trade deficit which will increase pressures for protection); and of the speed with which firms, workers, and consumers respond to incentives (sir, under this proposal a small low-wage firm pays $\$ 2,000$ less for health coverage for a minimum wage worker than a large firm, so if it is enacted 
you will see a lot of large firms fire their minimum-wage workers and a lot of small firms hire such workers).

Often the CEA gets flattened. To paraphrase one not-very-senior White House official, the public interest is just one more interest among many, so why should it deserve special consideration? To quote one ex-member of the Council of Economic Advisers, "in this business 0.250 is still a very, very good batting average." The logic of government is not allocative efficiency enforced by market discipline. The logic of government is the logic of politics: power exercised, influence used, and reciprocal favors returned. And it is not clear that this political logic is inappropriate for what are at bottom political questions.

But sometimes the CEA does make a microeconomic difference. And this may be its most significant contribution to economic welfare. That the CEA is able to make a positive contribution to the microeconomic efficiency of public policy is in large part the consequence of the staffing pattern established by Burns and Heller. Members and staff come from academic and think-tank positions, look forward to returning to academic positions, and view academic and think-tank researchers as the primary reference peer group whose approval they seek. Evelyn Waugh (1937) wrote of a tyrannical boss - Lord Beast - with whom people dared disagree only very gingerly: "Up to a point, Lord Beast." Those who make a career of government are well aware that those in authority are rarely pleased by bad news, and find themselves under immense pressure to say "up to a point..." The Council of Economic Advisers is somewhat less likely to say "Up to a point," when what is called for is "No!"

Perhaps this institutional capability to sometimes make a difference in terms of microeconomic efficiency is due to the operation of an Invisible Hand. Certainly it is not an outcome that anyone planned. Establishing in the White House staff a group of short-term employees with a primary allegiance to economists' sense of the public interest may have been the furthest thing from the minds of those who wrote Section 4 of the 1946 Employment Act. Their goal was to reduce the freedom of 
action of the President and his staff by fixing responsibility for stabilization policy planning on identifiable individuals chosen with the consent of the Senate.

\section{Conclusion: Hearts and Minds}

The principal key to understanding the 1946 Employment Act is that it should be taken as a signal: a signal that henceforth an administration that failed to achieve acceptable macroeconomic performance was a failed administration.

What if there had been no 1946 Employment Act? One possible answer is that things would have been little different: the same pressures that led to the passage of the 1946 Employment Act would still have existed. Fiscal and monetary policy would still have been shaped with both eyes on macroeconomic performance. And there would probably have been an Employment Act of 1947, or 1948 , or 1949.

A second possible answer is that there could have been no 1946 Employment Act only if the shifts in sentiment and opinion of which the 1946 Employment Act was a signal had not occurred, and if attitudes toward laissez-faire as a principle, toward government responsibility for the economy, and toward the likely effectiveness of government macroeconomic intervention in 1946 had been much more like attitudes in 1929.

A world in which opinion leaders and policy makers had not learned the lessons taught by the Great Depression and World War II would have been a very different world-presumably a world in which post-World War II macroeconomists called themselves Hayekians rather than Keynesians, discoursed on how deep recessions were a necessary price for the dynamic growth efficiencies of market-led economic development, and one in which governments responded to depressions by cutting spending and raising tax rates to keep the budget in balance (thus preventing investors from losing confidence and making the depression worse). In such a world an outbreak of inflation like that seen in the 1970 s would have been very unlikely. In such a world a repeat of the Great Depression would 
have been somewhat more likely. I do not think that many of us would think that it would have been a better world than the one in which we have lived for the past fifty years. But my opinion depends on a belief that the social and economic costs of the outbreak of inflation in the 1970s were low relative to the probability and cost of another episdoe like the Great Depression.

There is yet a third answer. In the absence of the particular institutional structure set up by the 1946 Employment Act, economists in government would have been fewer and less powerful. To some degree the then-Budget Bureau - now the Office of Management and Budget-and its director would have fulfilled missions now fulfilled by the CEA: career civil servants in Executive Branch cabinet departments do refer to OMB and CEA as "sister agencies," and many times the Director of OMB has been drawn from the set of economists also on the natural short list for CEA chair. ${ }^{4}$ But in the absence of the CEA to serve as an institutionalized voice for microeconomic efficiency, microeconomic efficiency as a goal of public policy would have likely played a smaller and feebler role in economic policy making.

\footnotetext{
${ }^{4}$ For example, think of George Shultz, Charles Schultze, or Alice Rivlin.
} 


\section{References}

Alan Auerbach, "The U.S. Fiscal Problem: Where We Are, How We Got Here, and Where We're Going," in NBER Macroeconomics Annual 1994, pp. 141-174.

Stephen Bailey, Congress Makes a Law: The Story Behind the Employment Act of 1946 (New York: Columbia University Press, 1950).

Ben Bernanke, "The Macroeconomics of the Great Depression : a Comparative Approach" (Cambridge, MA: NBER, 1994).

Douglass V. Brown et al., Economics of the Recovery Program (New York: McGraw-Hill, 1934).

James Buchanan and Richard Wagner, Democracy in Deficit: The Political Legacy of Lord Keynes (New York: Academic Press, 1977).

A.W. Coats, ed., Economists in Government: A General Comparative Study (Durham, NC: Duke University Press, 1981).

J. Bradford De Long and Lawrence H. Summers, "The Changing Cyclical Variability of Economic Activity in the United States," in Robert J. Gordon, ed., The American Business Cycle (Chicago: University of Chicago Press, 1986).

Robert Eisner, "Fiscal and Monetary Policy Reconsidered," American Economic Review 59 (1969), pp. 897-905.

Milton Friedman, "Stabilization Policy: A Formal Analysis," in Milton Friedman, Essays in Positive Economics (Chicago: University of Chicago, 1953).

Robert J. Gordon, "Postwar Macroeconomics: The Evolution of Events and Ideas," in Martin Feldstein, ed., The American Economy in Transition (Chicago: University of Chicago Press, 1980).

Robert J. Gordon, ed., Milton Friedman's Monetary Framework: A Debate with His Critics (Chicago: University of Chicago, 1972).

Gottfried Haberler, Prosperity and Depression: A Theoretical Analysis of Cyclical Movements (Geneva: League of Nations, 1937).

Ralph Hawtrey, A Century of Bank Rate (London: Longmans, Green, 1938). 
Friedrich Hayek, Prices and Production (London: Routledge and Kegan Paul, 1935).

Erwin C. Hargrove and Samuel A. Morley, The President and the Council of Economic Advisers: Interviews with CEA Chairmen (Boulder, CO: Westview Press, 1984).

Peter Hall, "Introduction," in Peter Hall, ed., The Political Power of Economic Ideas: Keynesianism Across Nations (Princeton: Princeton University Press, 1989).

Ralph Hawtrey, A Century of Bank Rate (London: Longmans, Green, 1938).

Walter Heller, New Dimensions of Political Economy (New York: W.W. Norton, 1966).

Carl Kaysen, "Model-Makers and Decision-Makers: Economists and the Policy Process," The Public Interest (Summer 1968), pp. 80-95.

John Maynard Keynes, An Economic Analysis of Unemployment (University of Chicago: Harris Foundation lectures, 1931).

Robert Nelson, "The Economics Profession and the Making of Economic Policy," Journal of Economic Literature (March 1987), pp. 49-90.

Arthur Okun, The Political Economy of Prosperity (Washington: Brookings Institution, 1970).

Lionel Robbins, The Great Depression (New York: Macmillan, 1934).

Christina Romer, "The Prewar Business Cycle Reconsidered : New Estimates of Gross National Product, 1869-1918” (Cambridge: NBER, 1986).

Walter Salant, "The Spread of Keynesian Doctrines and Practices in the United States," in Peter Hall, ed., The Political Power of Economic Ideas: Keynesianism Across Nations (Princeton: Princeton University Press, 1989).

Herbert Stein, The Fiscal Revolution in America (Chicago: University of Chicago Press, 1969).

Herbert Stein, “Comment on Robert Gordon, 'Postwar Macroeconomics: The Evolution of Events and Ideas'," in Martin Feldstein, ed., The American Economy in Transition (Chicago: University of Chicago Press, 1980).

Herbert Stein, Presidential Economics (New York: Simon and Schuster, 1984).

Peter Temin, Lessons from the Great Depression (Cambridge: M.I.T. Press, 1989). 
U.S. Government, Public Law 304 [Employment Act of 1946] 79th Cong., 2nd Sess., Feb. 20, 1946 (Washington: G.P.O.: 1946).

U.S. Government, Congress. Committee of Conference Report, A Bill Declaring a National Policy on Employment, Production, and Purchasing Power, and for Other Purposes 79th Cong., 2nd Sess.

(Washington: G.P.O.: 1946).

U.S. Government, Congress, House of Representatives Committee on Executive Department Expenditures, Full Employment Act of 1945: Hearings on H.R. 2202 79th Cong., 1st Sess (Washington: G.P.O., 1945).

Evelyn Waugh, Scoop (Boston: Little, Brown, 1938).

Margaret Weir, Politics and Jobs (Princeton, NJ: Princeton University Press, 1992). 